\title{
Volunteer Tourism: A Postcolonial Approach
}

\author{
Sasha Hanson Pastran*
}

\begin{abstract}
Volunteer tourism ("voluntourism," for short) is an alternative form of tourism in which tourists volunteer as part of their vacation in a developing country. ${ }^{1}$ It is often marketed as a mutually beneficial form of tourism, yet debate has arisen in recent years over the validity of this assessment and over the efficacy and ethics of using voluntourism as a development tool. ${ }^{2}$ The objectives of the paper are to: 1) examine the arguments in favour of volunteer tourism and to provide the postcolonial critiques of the industry, and 2) demonstrate how voluntourists and agencies can use a postcolonial approach to challenge and transform the neocolonial relationships embedded within this form of tourism. These objectives are met by critically examining the history, scope, and debate of the voluntourism industry through a postcolonial lens and by a brief discourse analysis of two case studies.
\end{abstract}

Keywords: volunteer tourism, voluntourism, postcolonial theory, neocolonialism, discourse analysis

\section{Introduction}

Volunteer tourism ("voluntourism," for short) is an alternative form of tourism in which tourists spend time volunteering as part of their vacation in a developing country. ${ }^{3}$ It is becoming increasingly popular and is hailed by some as sustainable, pro-poor, and mutually beneficial for both tourists and host communities. ${ }^{4}$ However, debate has arisen in recent years over the validity of these assessments and over the efficacy and ethics of using voluntourism as a development tool. 5

One of the biggest points of contention from critical scholars is the charge that voluntourism is simply a form of neocolonialism because it does little more than reinforce unequal power relationships and cultural stereotypes between tourists and hosts. ${ }^{6}$ Voluntourism is a broad category that encompasses a diverse set of actors, places, and activities; as a result, it is inevitable that some volunteer tourism ventures will be more effective than others at challenging this neocolonialism argument and achieving the vision of voluntourism as a mutually beneficial development tool.7 Considering this diversity, this paper has two objectives: 1) to examine the arguments in favour of volunteer tourism while critically assessing the colonial history, discourses, and paradoxes within the industry from a postcolonial perspective, ${ }^{8}$ and 2 ) to demonstrate how volunteer tourists and organizations can use a postcolonial approach to challenge the neocolonial relationships embedded in this form of tourism in order to engage in more mutually beneficial voluntourism activity.

In terms of organization, the paper first outlines the postcolonial analytical framework. It then provides an overview of the intersections of postcolonialism and tourism studies in general before going over the history, scope, and debate surrounding voluntourism in particular. Next, the study delves into a brief discourse analysis of two voluntourism organizations: Hero Holiday and Intercordia Canada. It concludes with a critical analysis of both the possibilities and limitations of using volunteer tourism as a development tool.

*International Studies Program, College of Arts and Science, University of Saskatchewan, Saskatoon, SK, Canada

Correspondence: sashahansonpastran@hotmail.com

University of Saskatchewan Undergraduate Research Journal Volume 1, Issue 1, 2014, 45-57 


\section{Analytical Framework: Postcolonial Theory}

This paper employs a postcolonial theoretical framework for its analysis of volunteer tourism. Broadly speaking, postcolonial theory "formulates its critiques around the social histories, cultural differences, and political discriminations that are practiced and normalized by the legacy of colonial and imperial machineries." 9 In other words, postcolonial theory draws attention to the legacies of colonialism and the structures of oppression that perpetuate colonial relationships between postcolonial geographies. ${ }^{10}$ This section provides a brief explanation of the history and core tenets of postcolonial theory in order to operationalize this framework of analysis for the study of volunteer tourism.

Postcolonial theory developed from the position that "development" was a Western imperial project to colonize now-independent postcolonial states in the Global South. ${ }^{11}$ This position came to the fore in the 1980s after decades of "development" in newly independent states had failed to achieve the goals of reducing poverty and inequality and promoting health, literacy, and sustained economic growth. ${ }^{12}$ Multiple disciplines in the Academy engaged in this critique of development, including women's and gender studies, economics, sociology, and political studies. Postcolonial theory is influenced to varying degrees by all of these disciplines and has consequently become an interdisciplinary critical theory.

At its simplest level, postcolonial theory posits that the historically proximate experience of colonialism has significant and continuing impacts on the political, economic, and social development of both the former colonizer and colonized. ${ }^{13}$ Furthermore, postcolonial theory aims to provide a basis for resistance and change of neocolonial narratives and relationships. ${ }^{14}$ In the words of postcolonial theorist Robert Young, "postcolonial theory disturbs the order of the world. It threatens privilege and power, [and i]t refuses to acknowledge the superiority of the western cultures." 15 The dual goal of postcolonialism is to deconstruct and reconstruct postcolonial narratives, and relationships are important for a critical yet productive exploration of such topics as volunteer tourism. With an understanding of the main tenets of postcolonialism, I now turn to situating discourse analysis within the postcolonial theoretical framework.

Critical theorists, including postcolonial theorists, understand discourse as socially constructed, historically and geopolitically situated, and underpinned by power dynamics. ${ }^{16}$ Since discourse is the medium used to understand reality or gain knowledge, the knowledgepower nexus that is created through the development and dissemination of particular discourses has real and lasting consequences for both Western and non-Western societies and serves as the starting point for a critique of development. Perhaps one of the best-known postcolonial theorists to engage in discourse analysis was Edward Said, who did so in his seminal work, Orientalism. ${ }^{17}$ Said's work focused on the ways in which Europe produced colonial discourses of the Orient (by which he meant not just the Middle East but all colonized geographies) in order to exert power over the colonized. ${ }^{18}$ In his words, "the Orient was almost a European invention, and had been since antiquity a place of romance, exotic beings, haunting memories and landscapes, [and] remarkable experiences."19 While postcolonial theory has since expanded from discourse analysis on the Orient, postcolonial theorists maintain the centrality of Said's ground-breaking work, contending that in the Global North, colonial discourses continue to dominate representations of the Global South. ${ }^{20}$ The contention about the neocolonial nature of development discourse is central to this paper's analysis of voluntourism.

In sum, postcolonial theory is situated within a critical arena where discourse is central to knowledge construction and power. Postcolonial theory's focus on both deconstruction and reconstruction is also instructive for critically analyzing volunteer tourism. A postcolonial approach to volunteer tourism is thus one in which volunteer tourists and agencies use critical analysis both to deconstruct the colonial history and development paradoxes inherent in volunteer tourism, as well as to reconstruct more equitable and mutually beneficial postcolonial relationships between voluntourists and the people they work with overseas. The next section intersects the ideas of postcolonialism and tourism more explicitly in order to develop this approach further.

\section{Postcolonialism in Tourism Studies}

Using postcolonial theory to analyze tourism seems like a natural fit, since the global tourism industry paralleled the rise of the post-World War II "development project," following the same directional global flows, and using the same structures of privilege, power, and hegemony. ${ }^{21}$ Tourism researchers Hazel Tucker and John Akama agree with this assessment, stating that "postcolonialism is a good framework for analyzing tourism because it reveals the neocolonial power relations on both structural and ideological levels." 22 A number of authors have utilized a postcolonial lens to analyze the mass tourism industry, and their analyses serve as the starting point for this particular study of volunteer tourism.

In terms of general tourism literature, John Urry's Tourist Gaze stands out as one of the first explicitly postcolonial texts. ${ }^{23}$ Urry found common ground with Said's 
work as he analyzed constructions of the "Other" in tourists" gazes and argued that they were based fundamentally on colonial myths. ${ }^{24}$ Charlotte Echtner and Pushkala Prasad built on Urry's work by developing a typology of three of the most common colonial myths that are reproduced in tourism marketing: "the myth of the unchanged," "the myth of a present-day paradise," and "the myth of the uncivilized." Together these represent places and people as firmly fixed in the past, sensuous, untouched, and untamed. ${ }^{25}$ The representations and myth constructions that surround tourism are simplified and based on dualities and differences rather than on hybrids or an acknowledgement of the multidimensional relationships between tourists and the places and people they encounter. ${ }^{26}$ It appears that this simplification serves to hide the commonalities and complex relationships between tourists and toured, and discourages self-reflection on tourists' neocolonial positionalities abroad, especially in the Global South. Therefore, according to Echtner and Prasad, "a colonial legacy of particular attitudes, images, and stereotypes continues to be reflected and reified" 27 by tourists through tourism marketing and activity. These authors' analyses show how discursive images and texts "define and fix both the tourist and the toured 'Other' in a relationship with each other which stem from colonialism and are always inherently colonial in nature. ${ }^{\prime 28}$

Other postcolonial tourism scholars such as Michael Hall and Hazel Tucker support Echtner and Prasad's work and similarly draw the connection between tourism and neocolonialism, but focus more attention on the neocolonial economic relations that are represented and reproduced within the international tourism industry. ${ }^{29} \mathrm{Hall}$ and Tucker explain how the tourism industry in developing countries is often developed by and responsive to external political and economic interests, thereby inducing high leakages of tourism revenues to external sources and accentuating dependencies between the core and the periphery. ${ }^{30}$

Economic neocolonialism is one of the main aspects of mainstream tourism that voluntourism aims to change. Yet volunteer tourism ventures must be aware of the inherent paradox of trying to transform the neocolonial effects of tourism without leaving the tourist industry all together. The following section provides an overview of the history and scope of voluntourism in order to contextualize the debate alluded to at the beginning of the paper.

\section{The History and Scope of Voluntourism}

Voluntourism is a relatively recent phenomenon that rose in prominence as part of a wave of alternative tourism niche markets that stood in opposition to mass tourism, beginning in the 1980 s. $^{31}$ Alternative tourist markets, which include ecotourism, ethical tourism, and volunteer tourism, are driven by a growing demand for tourism products that are more sustainable, participatory, pro-poor, and less harmful to local communities than mass tourism products have historically been. ${ }^{32}$ Alternative tourism is further underpinned by a belief that tourism can and should be beneficial not only to tourists and tourism agencies, but also to the communities that tourists visit. ${ }^{33}$ This belief in the potential for tourism to be mutually beneficial was not always the case for the mass tourism industry because it has historically been developed by external capital for external profit rather than for local development, as Hall and Tucker explained. ${ }^{34}$ This shift in the philosophy and practice of tourism is demonstrated by the fact that "Charity Tours" 35 are currently the fastest growing niche market in the tourism industry. ${ }^{36}$

Since its introduction in the 1980 , volunteer tourism has grown to include a variety of destinations, activities, time frames, and tourist types (different age groups, for example). This diversity complicates analyses of voluntourism since it is not a monolithic category. ${ }^{37}$ In order to understand the scope and diversity of this phenomenon, scholars Michelle Callanan and Sarah Thomas compiled a database of the main voluntourism industry categories from a large sample of voluntourism agencies and projects. ${ }^{38}$ Not surprisingly, they found that the top voluntourism destinations were mainly in the Global South, although Italy and England were also on the list. ${ }^{39}$ In their database, voluntourism activities ranged from building and community welfare projects, to teaching, business development, and environmental regeneration ventures..$^{40}$ They also found that the time frames ranged from less than two weeks to more than six months, and that the main volunteer tourist age group was youth (ages 18-30), and especially "gappers" (youth who take a so-called "gap year" during their studies). ${ }^{41}$ The diverse motivations of volunteer tourists have also been extensively studied by different authors. It was found that motivations include, but are not exclusive to desires to escape traditional tourism, enjoy new experiences, learn new skills, immerse oneself in a different culture, interact with the local people, "give back," "help where there is need," and "show love and concern." 42

Voluntourists themselves and voluntourism agencies should be aware of the diversity of their industry in order to identify and emulate the "best practices" that actually meet the marketing claims that drive this niche market. Knowing the diversity and scope of voluntourism is also helpful for contextualizing debates on the subject. There are many different examples and types of voluntourism from which to draw to support arguments both in favor of and in opposition to using volunteer tourism as a development tool, as some voluntourism ventures are inevitably more postcolonial than others. This diversity and selectivity should be kept in mind as the debate on voluntourism unfolds. 


\section{The Voluntourism Debate: Transformative Development Tool or Neocolonial Monster?}

As stated earlier, there is a polarized debate about the efficacy and ethics of voluntourism as a development tool. This section first provides an overview of the arguments from authors who have hailed the mutual benefits and development potential of voluntourism, and then contrasts this with the opinions from critical postcolonial scholars who are skeptical about the positive impacts of voluntourism and who see it instead as a new form of colonialism.

One of the most prolific writers on the benefits of volunteer tourism is Stephen Wearing. ${ }^{43}$ Wearing is an example of a voluntourism actor who takes a postcolonial approach to the study of volunteer tourism to challenge the argument that voluntourism is neocolonial. He asserts that, rather than a predetermined fall into purely neocolonial patterns and relations, there are spaces in voluntourism where the agency of the volunteer tourist, volunteer tour operators and suppliers, and members of the host community can overcome the dominant structures of colonial hegemony. ${ }^{44}$ It is possible to carve out these spaces because if proper sensitization and education about the colonial history and neocolonial structures of power are made explicit, the tourist in voluntourism is less the focal point of the tourism venture and is more an "equal part in the system of community, environment, and tourist." 45 This assessment is a good example of the potential of voluntourism projects to equalize historically neocolonial relationships if they are theorized and practiced through a critical theory model such as postcolonialism. ${ }^{46}$ In sum, Wearing sees a way to maximize the potential benefits and minimize potential negative impacts of voluntourism by following a critical postcolonial approach that recognizes the tourism industry's colonial past, while it imagines new possibilities for a more equal and conscientious postcolonial future. 47

Other authors build on Wearing's initial arguments and provide more evidence to support the claim that volunteer tourism can be beneficial to both tourists and the people they work with. For example, after an empirical evaluation of several voluntourism missions in Morocco, Corti, Marola, and Castro conclude that there were many positive contributions to both tourists and the local population in terms of social inclusion and development. ${ }^{48}$ Based on their findings, they assess voluntourism as "a sustainable [form] of international cooperation [and] development and an important way to promote social inclusion of less favored social classes [in] less developed countries." 49 Academics Alison J. Mclntosh and Anne Zahra echo their colleagues' analyses in their study of an Australian volunteer tourism project in a Maori community in New Zealand. ${ }^{\circ}$ Focusing on the cultural aspects of the voluntourism venture, they found evidence that the nature of the interaction and the cultural experiences gained were perceived as mutually beneficial and different from traditional tourist cultural products that were more neocolonial in nature. The authors found that volunteers were able to engage in the construction of a critical postcolonial cultural narrative, "one rich in authentic cultural content, genuine and reflective of modern Maori life in New Zealand society," ${ }^{51}$ through their work with their Maori hosts. To these authors, voluntourism seems beneficial for all parties. However, in order to provide a more nuanced argument in favour of voluntourism, some authors have qualified their claims with specific recommendations on how to increase the efficacy of voluntourism as a development tool.

In line with this paper's premise, the following authors argue that a postcolonial approach to volunteer tourism that includes critical sensitization and analysis is imperative for an equitable and effective voluntourism enterprise. ${ }^{52}$ For example, researchers Nancy McGehee and Carla Santos found that when coordinating organizations provide volunteers with opportunities for networking and consciousness-raising before, during, and after the voluntourism experience, there is more evidence of "a heightened awareness of social inequalities and injustices, the global nature of social issues, the recognition of the complexities of social issues, and the realization that it will take time and effort before effective and permanent change can occur."53 Consciousness-raising is squarely situated in the critical postcolonial model because it identifies and deconstructs the assumptions, tensions, and paradoxes of volunteering abroad. Thus, McGehee and Santos' recommendations would be of particular interest to voluntourists and organizations interested in challenging and transforming the neocolonial nature of their activities.

Another study by Nancy McGehee with her co-worker Kathleen Andereck on volunteering in Tijuana, Mexico, further supports the argument for critical postcolonial education and sensitization. ${ }^{54}$ The results of this study indicate that while all respondents were equally aware of volunteer tourism's positive consequences, those with greater critical consciousness and analytical skills were more likely to also be aware of the negative influences and the limitations of using volunteer tourism for development.55 These studies offer some evidence to support the arguments in favour of using voluntourism as a development tool, and also demonstrate how a postcolonial approach to volunteer tourism can increase the positive aspects of these ventures by revealing and challenging the 
colonial histories and power structures in which voluntourism enterprises are situated.

Other tourism researchers are not so optimistic about the transformative potential of volunteering abroad. In fact, quite a number of authors argue that voluntourism's inherent contradictions and shared history with colonialism are next to impossible to reconcile. ${ }^{56}$ Common points of entry for these postcolonial academics include the hegemonic neocolonial assumptions behind the discourse of volunteer tourism and the ways in which the practice of voluntourism reinforces neocolonial structures of power, privilege, and oppression. ${ }^{57}$ Furthermore, while acknowledging that volunteering abroad often bestows a wealth of benefits upon the volunteer, many authors are skeptical of any real, positive impact on host communities and importantly, seek host perspectives on the issue. ${ }^{8}$ Overall, postcolonial scholars' critiques offer important counterpoints to some of the arguments in favor of volunteer tourism and further this paper's thesis that voluntourists and agencies must honestly and actively challenge volunteer tourism's colonial past, its inherent contradictions, and the discourses and assumptions that perpetuate neocolonial relationships in order for their activities to be truly transformative and mutually beneficial.

One postcolonial approach to critiquing volunteer tourism is to deconstruct the assumptions and discourse behind the good intentions that many volunteers have. Kate Simpson, a staunch postcolonial critic of voluntourism, uses discourse analysis to argue that the "language of 'making a difference'... or 'contributing to the future of others' might be disguising a colonial development agenda and at the same time reinforcing unreflective volunteer practices."59 Researcher Harng Luh Sin also took this discourse analysis approach in her study on volunteer tourism and found that the main motivation for the volunteers in her cases was simply to go somewhere "exotic" - precisely a Saidian Orientalist notion!60 She further found that, contrary to pro-voluntourism studies, evidence of substantial changes in volunteers' value system, social consciousness, or willingness to volunteer in other arenas after volunteering abroad was statistically insignificant. ${ }^{61}$ Indeed, the multiple and often conflicting motivations of volunteer tourists often set up a paradox wherein they act like mature and benevolent travellers, while concomitantly they are not challenged to question their positionalities or their connections with and stereotypes about the "Other." Ultimately, this paradox reinforces the neocolonial construction of a dichotomy between the superior giver and the inferior "Other" aidrecipient in the voluntourism experience. ${ }^{62}$

Another voluntourism study by Carlos Palacios corroborates Sin's findings. Palacios cites a number of voluntourism cases in Mexico, Fiji, and Thailand where volunteer experiences did not seem to encourage critical reflections about poverty, but rather served to entrench volunteers' perceptions of their own superiority. ${ }^{6}$ Academic Mary Conran summarizes her colleagues' analyses, stating that the apolitical voluntourism discourse of "helping" and "giving" "overshadows the structural inequalities on which the encounter is based, reframes the question of structural inequality as a question of individual morality and perpetuates an apolitical cultural politics of volunteer tourism." ${ }^{64}$ These analyses suggest that actors in the voluntourism industry must more explicitly deconstruct and challenge the discourses surrounding peoples' motivations for volunteering abroad if changing values, consciousness raising, and mutually beneficial development are to occur.

The discourse that brings volunteers to developing countries is underpinned by a powerful neocolonial assumption that even inexperienced and unskilled Westerners can "bring development" to developing countries. $^{65}$ This assumption is revealed in rhetorical statements such as "teach a man to fish" - a phrase that implies that a Westerner, with little knowledge of the local contexts and resources, is somehow in a position to "teach" the local people how best to engage in development. ${ }^{66}$ This assumption is further demonstrated by the observation that fewer than 10 percent of volunteer "teaching" posts abroad require formal education training, according to the Callanan and Thomas database. ${ }^{67}$ In order to begin challenging this assumption, voluntourists and volunteer tourism agencies must be more critical of their own discourse and question the appropriateness of powerful labels such as "expert" or "teacher," which may inadvertently reproduce the neocolonial construction of Western superiority. ${ }^{68}$

Another strong point critics of volunteer tourism make concerns the structural inequality that is reproduced every time a volunteer tourism encounter occurs. By its nature, volunteer tourism brings together economically powerful volunteer tourists (who have enough discretionary economic resources to be able to afford a trip to volunteer abroad) with less powerful host communities (who are deemed "poor enough" to place them in the position of being "voluntoured"). This drastically unequal relationship cannot be ameliorated in the short time frame that most voluntourism ventures last. ${ }^{69}$ In the words of McGehee and Andereck, "this relationship in itself shatters any notion of human emancipation, and in fact can perpetuate inequality."70

Structural inequality is also perpetuated by particular conceptualizations of "development."71 To explain, Simpson offers a clear statement problematizing the simplistic, externalized, and neocolonial development discourse that underpins the perpetuation of structural inequality in voluntourism: 
The first point to make about this discourse is the way 'development' is seen as something that can be 'done', and specifically, by non-skilled, but enthusiastic, volunteer-tourists ${ }^{72} \ldots$ [which] perpetuates a simplistic ideal of development, [and] in turn legitimizes the validity of young unskilled Western labour as a development 'solution'73... encouraging the 'third world' to follow the west's example, and offering volunteers to set that example. ${ }^{74}$

This analysis of the structural inequality of voluntourism raises serious questions about the efficacy of using volunteer tourism as a tool for equitable and sustainable development. Clearly, if volunteer tourism is to break from neocolonial power structures, the history, discourses, and assumptions behind the industry must at a minimum be problematized and challenged. A look at the impact of volunteer tourism from the perspective of host communities is also imperative to understanding and changing the neocolonial relationships within this form of development.

The lack of academic attention to the perspectives of host communities is telling of the assumptions that surround volunteer tourism; the host community is irrelevant in the equation of "development" that is simply, generously, and neutrally bestowed upon it by Western volunteers. It is also telling that, contrary to the strong evidence of the many benefits of voluntourism for volunteers, the impact of volunteer tourism on host communities is often mixed. ${ }^{75}$ In fact, both Guttentag and Simpson indicate that some forms of volunteer tourism may even burden host communities while reinforcing dependency on externalized development aid in the form of volunteers. ${ }^{76}$ For example, Guttentag found evidence of such negative impacts as "the neglect of local resident's desires, unsatisfactory or incomplete work conducted by volunteers, the reduction of potential employment for locals, the promotion of dependency, and the 'othering' of locals."77 Palacios's voluntourism study upholds Guttentag's conclusions, finding that many times, the interests of sending countries and organizations prevailed over local ones, and that the benefits were almost always weighted towards the volunteers. ${ }^{78}$ Overall, these authors suggest that voluntourism ventures have a low and even negative impact in host communities because the volunteers often do not have enough knowledge or reflection capacity, ${ }^{79}$ appropriate skills or qualifications, ${ }^{80}$ volunteering and international experience, time to integrate and build trust with the locals, ${ }^{81}$ or altruistic intentions.

Overall, after reviewing both sides of the volunteer tourism debate, both the prospects and limits of voluntourism appear clearer. This paper finally turns to some specific case studies in order to underline the argument that volunteer tourists and sending agencies should engage in a postcolonial approach to the discourse and practice of voluntourism in order to begin to challenge and transform the neocolonial relationships embedded in this form of tourism.

\section{Volunteer Tourism Case Studies: Hero Holiday and Intercordia Canada}

This section delves into a postcolonial discourse analysis of two voluntourism case studies: the Live Different organization, which facilitates short Hero Holiday humanitarian trips to a number of Latin American countries, and Intercordia Canada, which also focuses on Latin America but has volunteer posts in Africa and Eastern Europe as well. ${ }^{82}$ The two volunteer tourism organizations were chosen because they are both based in Canada and they are both registered charities, yet they have several important differences that facilitate comparison and discussion. I will deconstruct and compare the marketing discourses of the two organizations' websites and assess their level of postcolonial orientation, which inevitably affects the program volunteers and the host communities.

The first case study explores the discourse of Live Different's advertisements for their Hero Holidays. The main Hero Holiday website advertises its program in this way:

Have you ever wanted to do something tangible that made a difference for those who have no voice or opportunity? Have you ever wanted to expand and challenge your global perspective? Have you ever wanted to learn more about how you can be a voice for those who have no voice? You can! Join us on a Hero Holiday! ${ }^{3}$

Here, the discourse of "making a difference for those who have no voice or opportunity" is problematic in a number of ways. First, the uncritical construction of the monolithic, voiceless "Other" (unquestionably referring to the host community) denies a considerable degree of the host community's agency as it creates an image of helpless subalterns in need of a savior. Second, the response to "be the voice" is based on a neocolonial position that subalterns cannot and should not speak for themselves, but rather that Western volunteers should embody their space and speak for them. While these messages clearly point to neocolonialism, they are somewhat countered by the call to "expand and challenge one's global perspective," which implies a questioning of positionality and the global structures that create inequality, oppression, and neocolonialism. However, in the context of a clearly neocolonial discourse it is difficult to assess this sentence so optimistically. Even the title "Hero Holiday" carries with it 
strong notions of Western superiority and emphasizes the tourism side of the volunteer tourism experience, which together lead to the assessment of an uncritical and neocolonial voluntourism venture. Nonetheless, this marketing statement demonstrates the tensions encapsulated by voluntourism organizations such as Live Different, which may have altruistic intentions but participate in practices that perpetuate neocolonialism.

The second case study concerns the Intercordia Canada program. In contrast to Hero Holiday, Intercordia's approach to volunteering abroad is based on a servicelearning approach that emphasizes critical analysis of the history, relationships, and global forces that perpetuate inequality and oppression in the Global South. ${ }^{84}$ In this regard, the organization is already oriented towards a critical postcolonial perspective that actively reveals and challenges the power relationships in which volunteers and host communities find themselves entwined. Another difference between the Hero Holiday program and Intercordia is that Intercordia volunteer posts are mediumterm projects, typically around three months long, whereas the Hero Holiday projects are usually about two weeks in duration. ${ }^{85}$ The longer duration of Intercordia's programs implies a firmer commitment to integration and relationship building between volunteers and people in their host communities, which has obvious potential for reconstructing North-South relations along postcolonial lines. Intercordia's "Mission and Goals" statement supports this assessment and stands in place of the flashy marketing phrases that Live Different uses, further differentiating the two organizations. According to Intercordia:

The goal of this innovative learning program is to encourage moral responsiveness, develop respect for diversity and a valuing of other cultures, religions and socio-economic backgrounds that will enable Canadian students to attain a welleducated solidarity with others who are different. ${ }^{86}$ After comparing the two case studies, it is clear that the discourse of Intercordia Canada is more carefully and critically crafted and more oriented towards a postcolonial perspective than Hero Holiday's discourse. However, it is still imperative to be critical and reveal Intercordia's emphasis on difference, as opposed to similarity or interconnection. The danger of this emphasis on difference is that the interconnections and complex relationships between the volunteers and their hosts are made less explicit and therefore harder to deconstruct and challenge. Furthermore, while Intercordia's use of service-learning is a positive sign, this methodology is still focused primarily on benefitting the volunteer rather than equalizing historically unequal relationships between volunteers and hosts. ${ }^{87}$ Nonetheless, Intercordia's use of terms such as "solidarity," "respect," and "valuing of others" in its discourse leads to a positive assessment of the organization's critical postcolonial stance and its transformative potential.

This short exploration of two opposing case studies shows not only the range of volunteer tourist organizations and discourses but also demonstrates the challenges that volunteer organizations face when it comes to reconciling the neocolonial relationships and inherent paradoxes that exist within the field of voluntourism. The case studies further exemplify how a critical postcolonial perspective can orient voluntourists and voluntourism organizations away from their neocolonial tendencies and towards more emancipatory development ends through a critical analysis of colonial histories and other global forces that perpetuate inequality.

\section{Conclusion}

This paper has argued that volunteer tourism actors should critically analyze voluntourism's colonial history and its inherent limitations as a development tool through a postcolonial lens in order to begin to transform the neocolonial relationships and discourses in this form of tourism. I have developed this argument by framing the debate concerning volunteer tourism in the language of postcolonial theory, surveying the literature from both critics and supporters of voluntourism, and deconstructing the discourse of two volunteer tourist case studies. Undoubtedly, the debate over the efficacy and legitimacy of volunteer tourism as a development tool is far from over, as scholars, voluntourism agencies, and development practitioners continue to argue for either side. The future outcome of this debate is unclear, but this paper will hopefully contribute to the literature on this topic with a clear proposition of fusing volunteer tourism with postcolonialism.

\section{Acknowledgements}

I wish to acknowledge and thank my International Studies 402 course instructor Dr. Martin Gaal for accepting this paper in his class and encouraging me to seek speaking engagements and publishing opportunities with my research on this topic.

\section{Bibliography}

Barbieri, Carla, Carla Almeida Santos, and Yasuharu Katsube. "Volunteer Tourism: On-the-ground Observations from Rwanda." Tourism Management 33, no. 3 (2012): 509-516. 
Barkham, P. "Are These the New Colonialists?" The Guardian, August 18, 2006.

http://www.guardian.co.uk/society/2006/aug/18/interna tionalaidanddevelopment.education.

Barnett, C., and D. Land. "Geographies of Generosity: Beyond the 'Moral Turn.' " Geoforum 38, no. 6 (2007): 1065-1075.

Bourdieu, P. "Marginalia: Some Additional Notes on the Gift." In The Logic of the Gift: Toward an Ethic of Generosity, edited by A.D. Schrift, 231-241. New York: Routledge, 1997.

Burnell, Peter, Vicky Randall, and Lise Rakner, eds. Politics in the Developing World. Oxford: Oxford University Press, 2008.

Butcher, J. "A Humanistic Perspective on the VolunteerRecipient Relationship: A Mexican Study." In Nonprofit and Civil Society Studies. The Values of VolunteeringCross-Cultural Perspectives, edited by P. Dekker and L. Halman, 111-126. New York: Kluwer Academic, 2003.

Butin, D. W. "Of What Use Is It? Multiple Conceptualizations of Service-Learning in Education." Teachers College Record 10, no. 5 (2003): 1674-1692.

Brown, F., and D. Hall. "Tourism and Development in the Global South: The Issues." Third World Quarterly 29, no. 5 (2008): 839-849.

Callanan, M., and S. Thomas. "Volunteer TourismDeconstructing Volunteer Activities Within a Dynamic Environment." In Niche Tourism: Contemporary Issues, Trends and Cases, edited by Marina Novelli, 183-200. New York: El Sevier, 2005.

Chen, Li-Ju, and Joseph S. Chen. "The Motivations and Expectations of International Volunteer Tourists: A Case Study of 'Chinese Village Traditions.' " Tourism Management 32, no. 2 (2011): 435-442.

Chiriyankandath, James. "Colonialism and Post-Colonial Development." In Politics in the Developing World, edited by Peter Burnell, Vicky Randall, and Lise Rakner, 35-52. Oxford: Oxford University Press, 2008.

Conran, Mary. "They Really Love Me! Intimacy in Volunteer Tourism." Annals of Tourism Research 38, no. 4 (2011): 1454-1473.

Corti, I. N., P.N. Marola, and M.B. Castro. "Social Inclusion and Local Development Through European Voluntourism: A Case Study of the Project Realized in a Neighborhood of Morocco." American Journal of Economics and Business Administration 2, no. 3 (2010): 221-231.

Dekker, P., and L. Halman, eds. Nonprofit and Civil Society Studies. The Values of Volunteering-Cross-Cultural Perspectives. New York: Kluwer Academic, 2003.

Denzin, N., and S. Lincoln, eds. The Handbook of Qualitative Research. Thousand Oaks, CA: Sage, 2003.
Dhruvarajan, V. "Globalization: Discourse of Inevitability, and a Quest for a Just and Caring World." Society-Société 24, no. 2 (2000): 1-12.

Echtner, Charlotte M., and Pushkala Prasad. "The Context of Third World Tourism Marketing." Annals of Tourism Research 30, no. 3 (2003): 660-682.

Gandhi, L. Postcolonial Theory: A Critical Introduction. New York, NY: Columbia University Press, 1998.

Glyptis, S., ed. Leisure and the Environment: Essays in Honour of Professor J.A. Patmore. London: Belhaven Press, 1993.

Guttentag, D. "The Possible Negative Impacts of Volunteer Tourism." International Journal of Tourism Research 11, no. 6 (2009): 537-551.

Griffiths, P. "Charity Attacks Gap-Year 'Volunteerism.' " Reuters, August 14, 2007. http://uk.reuters.com/article/2007/08/14/uk-britaintravel-gap-idUKL1465130020070814.

Hall, C. Michael, and Hazel Tucker, eds. Tourism and Postcolonialism: Contested Discourses, Identities and Representations. London: Routledge, 2004.

Haslam, Paul, Jessica Schafer, and Pierre Beaudet, eds. An Introduction to International Development: Approaches, Actors and Issues, 2nd Edition. Don Mills: Oxford University Press, 2011.

"Hero Holiday Homepage." Live Different. Accessed January 20, 2012. http://livedifferent.com/hero-holiday.

Hopkins, Laura. "Post-Colonialism and Critical Medical Anthropology." University of Saskatchewan Presentation, June 2, 2011.

Horkheimer, M. Critical Theory. New York: Seabury Press, 1982.

"Homepage." Intercordia Canada. Accessed January 20, 2012. http://www.intercordiacanada.org/index.php.

"What We Do." Intercordia Canada. Accessed January 20, 2012. http://www.intercordiacanada.org/index.php/what-wedo/.

Jamal, Tazim, and Mike Robinson, eds. The SAGE Handbook of Tourism Studies. Washington, DC: SAGE, 2009.

Kincheloe, J., and P. McLaren. "Rethinking Critical Theory and Qualitative Research." In The Handbook of Qualitative Research, edited by N. Denzin and S. Lincoln, 279-313. Thousand Oaks, CA: Sage, 2003.

Klaushofer, A. " 'Voluntourists' Told Not to Bother." World Volunteer Web. May 4, 2010. Accessed January 16, 2012. http://www.worldvolunteerweb.org/join-thenetwork/blogs/doc/gap-year-voluntourists-toldnot.html.

Kwa, T. "Voluntourism: More Tourist than Volunteer." The Straits Times. July 28, 2007. Accessed January 15, 2012. http://library.thinkquest.org/o7aug/oo6g8/tionkwa.html. 
Lo, Ada S., and Candy Y.S. Lee. "Motivations and Perceived Value of Volunteer Tourists From Hong Kong." Tourism Management 32, no.2 (2011): 326-334.

McGehee, Nancy Gard. "Oppression, Emancipation, and Volunteer Tourism: Research Propositions." Annals of Tourism Research 39, no. 1 (2012): 84-107.

McGehee, Nancy Gard, and Carla Almeida Santos. "Social Change, Discourse and Volunteer Tourism." Annals of Tourism Research 32, no. 3 (2005): 760-779.

McGehee, Nancy Gard, and Kathleen Andereck. " 'Pettin' the Critters': Exploring the Complex Relationship Between Volunteers and the Voluntoured in McDowell County, WV, USA and Tijuana, Mexico." In Journeys of Discovery in Volunteer Tourism: International Case Study Perspectives, edited by S. Wearing and K. Lyons, 12-24. Oxfordshire, UK: CABI, 2008.

McGehee, Nancy Gard, and Kathleen Andereck. "Volunteer Tourism and the 'Voluntoured': The Case of Tijuana, Mexico." Journal of Sustainable Tourism 17, no. 1 (2009): 39-51.

Mclntosh, Alison J., and Anne Zahra. "A Cultural Encounter through Volunteer Tourism: Towards the Ideals of Sustainable Tourism?" Journal of Sustainable Tourism 15, no. 5 (2007): 541-556.

Mishra, V., and B. Hodge. "What is Post(-)Colonialism?" Textual Practice 5, no. 3 (1991): 399-414.

Morris A., and C. Mueller, eds. Frontiers in Social Movement Theory. New Haven: Yale University Press, 1992.

Mueller, C. "Building Social Movement Theory" In Frontiers in Social Movement Theory, edited by A. Morris and C. Mueller, 12-45. New Haven: Yale University Press, 1992.

Novelli, Marina, ed. Niche Tourism: Contemporary Issues, Trends and Cases. New York: El Sevier, 2005.

Palacios, Carlos M. "Volunteer Tourism, Development and Education in a Postcolonial World: Conceiving Global Connections Beyond Aid." Journal of Sustainable Tourism 18, no. 7 (2010): 861-878.

Raymond, Eliza Marguerite, and C. Michael Hall. "The Development of Cross-Cultural (Mis)Understanding Through Volunteer Tourism." Journal of Sustainable Tourism 16, no. 5 (2008): 530-543.

Sahle, Eunice N. "Post-development." In An Introduction to International Development: Approaches, Actors and Issues, 2nd Edition, edited by Paul Haslam, Jessica Schafer, and Pierre Beaudet, 66-82. Don Mills: Oxford University Press, 2011.

Said, E.W. Orientalism: Western Conceptions of the Orient. London: Penguin, 1978.

Schrift, A.D., ed. The Logic of the Gift: Toward an Ethic of Generosity. New York: Routledge, 1997.

Silk, J. "Caring at a Distance: Gift Theory, Aid Chains and Social Movements." Social and Cultural Geography 5, no. 2 (2004): 229-251.
Sim, S., and B. Van Loon. Introducing Critical Theory: A Graphic Guide. London: Icon Books, 2009.

Simpson, K. " 'Doing Development': The Gap Year, Volunteer-tourists and a Popular Practice of Development." Journal of International Development 16, no. 5 (2004): 681-692.

Sin, Harng Luh. "Volunteer Tourism-'Involve Me and I Will Learn'?" Annals of Tourism Research 36, no. 3 (2009): 480-501.

---. "Who are We Responsible To? Locals' Tales of Volunteer Tourism." Geoforum 41, no. 6 (2010): 983-992.

Singh, Tej Vir, ed. New Horizons in Tourism: Strange Experiences and Stranger Practices. Cambridge, MA: CABI Publishing, 2004.

Singh, Shalini, and Tej Vir Singh. "Volunteer Tourism: New Pilgramiges to the Himalayas." In New Horizons in Tourism : Strange Experiences and Stranger Practices, edited by Tej Vir Singh, 181-194. Cambridge, MA: CABI Publishing, 2004.

Stebbins, R., and M. Graham, eds. Volunteering as Leisure/ Leisure as Volunteering - an International Assessment. Wallingford, UK: CABI Publishing, 2004.

Steinback, J. The Log from the Sea of Cortez. London: Penguin, 1951.

Tallantire, J. "Adventure Tourism in Remote Places." In Leisure and the Environment: Essays in Honour of Professor J.A. Patmore, edited by S. Glyptis, 279-292. London: Belhaven Press, 1993.

Tucker, Hazel, and John Akama. "Tourism as Postcolonialism." In The SAGE Handbook of Tourism Studies, edited by Tazim Jamal and Mike Robinson, 504520. Washington, DC: SAGE, 2009.

Urry, John. The Tourist Gaze. London: Sage, 1990.

Young, R. Postcolonialism: A Very Short Introduction. Oxford: Oxford University Press, 2003.

Wearing, S.L. "Examining Best Practice in Volunteer Tourism." In Volunteering as Leisure/ Leisure as Volunteering - an International Assessment, edited by R. Stebbins and M Graham, 209-224. Wallingford, UK: CABI Publishing, 2004.

Wearing, S. L. Volunteer Tourism: Experiences That Make a Difference. Oxon, UK: CABI Publishing, 2001.

Wearing, S. L., and K. Lyons, eds. Journeys of Discovery in Volunteer Tourism: International Case Study Perspectives. Oxfordshire, UK: CABI Publishing, 2008.

Wearing, S.L., and K. Lyons. International Volunteer Tourism: Integrating Travellers and Communities. UK: CABI Publishing, 2011.

Wearing, S. L., and M. Wearing. "Rereading the Subjugating Tourist in Neoliberalism: Postcolonial Otherness and the Tourist Experience." Tourism Analysis 11, no. 2 (2006): 145-162. 
1 Sin, "Volunteer Tourism,"' 480. Another commonly cited definition of volunteer tourism comes from Stephen Wearing's book Volunteer Tourism: Experiences That Make a Difference, which states that: "[v]olunteer tourism combines travel with voluntary work, attracting individuals that 'are seeking a tourist experience that is mutually beneficial, that will contribute not only to their personal development but also positively and directly to the social, natural and/or economic environments in which they participate' " (1). For more information on what constitutes 'volunteer tourism' see: http://www.voluntourism.org/index.html.

2 Dhruvarajan, "Globalization: Discourse of Inevitability," 1-12; McGehee, "Oppression, Emancipation, and Volunteer Tourism," 84, 95; McGehee and Andereck, "Exploring the Complex Relationship Between Volunteers and the Voluntoured," 12-24; Raymond, "Cross-Cultural (Mis)Understanding Through Volunteer Tourism," 530-43; Sin, "Volunteer Tourism," 480501.

3 Sin, "Volunteer Tourism,"' 480.

4 Callanan and Thomas, "Volunteer Tourism- Deconstructing Volunteer Activities," 185; Corti et al., "Local Development through European Voluntourism," 221-31; McIntosh and Zahra, "A Cultural Encounter through Volunteer Tourism," 541-56; Novelli, Niche Tourism: Contemporary Issues, 2-10; Sin, "Volunteer Tourism," 480; Singh and Singh, "New Pilgrimages to the Himalayas," 181-94; Wearing, Volunteer Tourism: Experiences that Make a Difference.

5 Dhruvarajan, "Globalization: Discourse of Inevitability," 1-12; McGehee, "Oppression, Emancipation, and Volunteer Tourism," 84, 95; McGehee and Andereck, "Exploring the Complex Relationship Between Volunteers and the Voluntoured," 12-24; Raymond, "Cross-Cultural (Mis)Understanding Through Volunteer Tourism," 530-43; Sin, "Volunteer Tourism," 480501.

6 Barkham, "Are these the New Colonialists?," 12-14; Brown and Hall, "Tourism and Development in the Global South," 845; Griffiths, "Charity Attacks Gap-Year 'Volunteerism' "; Klaushofer, " 'Voluntourists' told not to Bother"; Simpson,

" 'Doing Development': The Gap Year, Volunteer-Tourists," 681-92; Sin, "Volunteer Tourism," 480-501.

7 Callanan and Thomas, "Volunteer Tourism- Deconstructing Volunteer Activities," 187-95; Dhruvarajan, "Globalization: Discourse of Inevitability," 1-12; Sin, "Volunteer Tourism," 480.

8 Sin, "Who Are We Responsible To?," 983-92; McGehee, "Oppression, Emancipation, and Volunteer Tourism," 85; Simpson, "'Doing Development': The Gap Year, Volunteer-Tourists," 681-92.

9 Hopkins, "Post-Colonialism and Critical Medical Anthropology" Presentation, June 2, 2011.

10 Kincheloe and McLaren, "Rethinking Critical Theory," 88-89; Sim and Van Loon, Introducing Critical Theory; Tucker, "Tourism as Postcolonialism," 504.

11 Sahle, "Post-development," 66-67.

12 Sahle, "Post-development," 66-82.

13 However, as postcolonialism academic James Chiriyankandath points out, postcolonial theory complicates its analysis of the impacts of colonialism by looking at the ways differences in resources and political agency after independence and continuing forms of resistance to neocolonialism have also played their parts in the production of the varied political, economic, and social realities found across the postcolonial world. Chiriyankandath, "Colonialism and PostColonial Development," 35-52.

14 Tucker, "Tourism as Postcolonialism," 504-5.

15 Young, Postcolonialism, 7.

16 Horkheimer, Critical Theory; Sahle, "Post-development," 66-67.

17 Said, Orientalism.

18 Said, Orientalism. Also see: Gandhi, Postcolonial Theory.

19 Said, Orientalism, 1.

20 Mishra, "What is Post(-)Colonialism?" 399-414i Tucker, "Tourism as Postcolonialism," 505. 
21 Tucker, "Tourism as Postcolonialism," 506.

22 Tucker, "Tourism as Postcolonialism," 504-20.

23 Urry, The Tourist Gaze.

24 Urry, The Tourist Gaze, 511.

25 Echtner and Prasad, "The Context of Third World Tourism Marketing," 660-82.

26 Tucker, "Tourism as Postcolonialism," 516.

27 Echtner and Prasad, "The Context of Third World Tourism Marketing," 660.

28 Tucker, "Tourism as Postcolonialism," 510.

29 Hall and Tucker, Tourism and Postcolonialism.

30 Hall and Tucker, Tourism and Postcolonialism, 506-7.

31 Callanan and Thomas, "Volunteer Tourism- Deconstructing Volunteer Activities," 185.

32 Callanan and Thomas, "Volunteer Tourism- Deconstructing Volunteer Activities," 185; Novelli, Niche Tourism: Contemporary Issues, 2-10; Singh and Singh, "New Pilgrimages to the Himalayas," 181-94.

33 Novelli, Niche Tourism: Contemporary Issues, 2-10; Sin, "Volunteer Tourism,"' 482.

34 Hall and Tucker, Tourism and Postcolonialism, 506-7.

35 "Charity Tours" are a type of volunteer tourism wherein the monetary and resource donations of tourists are the main components of the 'volunteering' portion of their vacation. Tours to the places that the donations go to are also often part of the trip. For more information see: Callanan and Thomas, "Volunteer Tourism- Deconstructing Volunteer Activities," $183-200$.

36 Callanan and Thomas, "Volunteer Tourism- Deconstructing Volunteer Activities," 185.

37 Callanan and Thomas, "Volunteer Tourism- Deconstructing Volunteer Activities," 183-200. See also: McGehee, "Oppression, Emancipation, and Volunteer Tourism: Research Propositions," 84-107.

38 Callanan and Thomas, "Volunteer Tourism- Deconstructing Volunteer Activities," 187-95.

39 Callanan and Thomas, "Volunteer Tourism- Deconstructing Volunteer Activities," 192-93.

40 Callanan and Thomas, "Volunteer Tourism- Deconstructing Volunteer Activities," 192.

41 Callanan and Thomas, "Volunteer Tourism- Deconstructing Volunteer Activities," 187-95. Also see: Simpson, " 'Doing Development': The Gap Year, Volunteer-Tourists," 681-692.

42 Chen and Chen, "The Motivations and Expectations of International Volunteer Tourists," 435-42; Corti et al., "Local Development through European Voluntourism," 221-31; Lo and Lee, "Motivations and Perceived Value of Volunteer Tourists," 326-34.

43 Some of Wearing's contributions to volunteer tourist literature include: Wearing, Volunteer Tourism: Experiences that Make a Difference; Wearing, "Examining Best Practice in Volunteer Tourism"; Wearing and Lyons, Journeys of Discovery in Volunteer Tourism; Wearing and Lyons, International Volunteer Tourism: Integrating Travellers and Communities; and Wearing and Wearing, "Rereading the Subjugating Tourist in Neoliberalism," 145-62.

44 Wearing and Wearing, "Rereading the Subjugating Tourist in Neoliberalism," 145-62. Also see: Barbieri, "Volunteer Tourism: On-the-ground Observations," 509-516, for more discussion of the various actors involved in executing transformative voluntourism ventures.

45 Wearing, Volunteer Tourism: Experiences that Make a Difference, 162.

46 Wearing, Volunteer Tourism: Experiences that Make a Difference, x. For an example of an emancipatory critical theory model to voluntourism see Figure 1, from McGehee, "Oppression, Emancipation, and Volunteer Tourism," 98.

47 Wearing and Wearing, "Rereading the Subjugating Tourist in Neoliberalism," 145-62.

48 Corti et al., "Local Development through European Voluntourism," 221-31.

49 Corti et al., "Local Development through European Voluntourism," 221.

50 Mclntosh and Zahra, "A Cultural Encounter through Volunteer Tourism," 541-56.

51 Mclntosh and Zahra, "A Cultural Encounter through Volunteer Tourism," 541.

52 Sin, "Volunteer Tourism," 496.

53 McGehee and Santos, "Social Change, Discourse and Volunteer Tourism," 771. 
54 McGehee and Andereck, "Volunteer Tourism and the 'Voluntoured,'" 39-51.

55 McGehee and Andereck, "Volunteer Tourism and the 'Voluntoured," " 47.

56 Dhruvarajan, "Globalization: Discourse of Inevitability," 1-12; McGehee, "Oppression, Emancipation, and Volunteer Tourism," 84, 95; McGehee and Andereck, "Exploring the Complex Relationship Between Volunteers and the Voluntoured," 12-24; Sin, "Volunteer Tourism," 480-501.

57 Barkham, "Are these the New Colonialists?," 12-14; Brown and Hall, "Tourism and Development in the Global South," 845; Griffiths, "Charity Attacks Gap-Year 'Volunteerism' "; Klaushofer, " 'Voluntourists' told not to Bother"; Simpson, "'Doing Development': The Gap Year, Volunteer-Tourists," 681-92; Sin, "Volunteer Tourism," 480-501.

58 Kwa, "Voluntourism: More Tourist than Volunteer"; Sin, "Who are we Responsible to?," 983-84.

59 Simpson, "'Doing Development': The Gap Year, Volunteer-Tourists," 68.

60 Sin, "Volunteer Tourism," 481.

61 Sin, "Volunteer Tourism," 481.

62 Barnett and Land, "Geographies of Generosity," 1065-75; Butcher, "A Humanistic Perspective on the VolunteerRecipient Relationship," 111-26; Sin, "Volunteer Tourism," 495; Silk, "Gift Theory, Aid Chains and Social Movements," 22951.

63 Palacios, "Volunteer Tourism, Development and Education," 861-78.

64 Conran, "Intimacy in Volunteer Tourism," 1454; Steinback, The Log from the Sea of Cortez, 282: Tallantire, "Adventure Tourism in Remote Places," 279-92.

65 Brown and Hall, "Tourism and Development in the Global South," 845; Sin, "Who are we Responsible to?," 987.

66 Sin, "Who are we Responsible to?," 987.

67 Callanan and Thomas, "Volunteer Tourism- Deconstructing Volunteer Activities," 193.

68 Raymond et al., "Cross-Cultural (Mis)Understanding Through Volunteer Tourism," 531.

69 McGehee, "Oppression, Emancipation, and Volunteer Tourism," 100.

70 McGehee and Andereck, "Exploring the Complex Relationship Between Volunteers and the Voluntoured," 12.

71 Simpson, "'Doing Development': The Gap Year, Volunteer-Tourists," 682, 684-85.

72 Simpson, "'Doing Development': The Gap Year, Volunteer-Tourists," 684.

73 Simpson, "'Doing Development': The Gap Year, Volunteer-Tourists," 682.

74 Simpson, "'Doing Development': The Gap Year, Volunteer-Tourists," 686.

75 Guttentag, "The Possible Negative Impacts of Volunteer Tourism," 537-51; Simpson, "'Doing Development': The Gap Year, Volunteer-Tourists," 681-92.

76 Guttentag, "The Possible Negative Impacts of Volunteer Tourism," 537; Simpson, "'Doing Development': The Gap Year, Volunteer-Tourists," 681-92. For more discussion on the reinforcement of dependent relationships between the North and South, see: Bourdieu, "Marginalia: Some Additional Notes on the Gift," 231-41.

77 Guttentag, "The Possible Negative Impacts of Volunteer Tourism," 537.

78 Palacios, "Volunteer Tourism, Development and Education," 861.

79 Simpson, "'Doing Development': The Gap Year, Volunteer-Tourists," 682.

80 McGehee and Andereck, "Exploring the Complex Relationship Between Volunteers and the Voluntoured," 12-24; Raymond et al., "Cross-Cultural (Mis)Understanding Through Volunteer Tourism," 530.

81 Brown and Hall, "Tourism and Development in the Global South," 845.

82 Hero Holiday Homepage, accessed January 20, 2012, http://ivedifferent.com/hero-holiday; Intercordia Canada Homepage, accessed January 20, 2012, http://www.intercordiacanada.org/index.php.

83 Hero Holiday Homepage, accessed January 20, 2012, http://livedifferent.com/hero-holiday.

84 Intercordia Canada Homepage, accessed January 20, 2012, http://www.intercordiacanada.org/index.php.

85 Hero Holiday Homepage, accessed January 20, 2012, http://livedifferent.com/hero-holiday; Intercordia Canada "What We Do" webpage, accessed January 20, 2012, http://www.intercordiacanada.org/index.php/what-we-do/.

86 Intercordia Canada "What We Do" webpage, accessed January 20, 2012, http://www.intercordiacanada.org/index.php/what-we-do/. 
87 Intercordia Canada "What We Do" webpage, accessed January 20, 2012, http://www.intercordiacanada.org/index.php/what-we-do/ . For a more detailed critique of the service-learning perspective, see: Butin, D. W., "Of What Use Is It?," 1674-92. 